УДК 346.546

DOI https://doi.org/10.32849/2663-5313/2020.10.08

\title{
Веста Малолітнева,
}

канд. юрид.наук,

учений секретар

Інституту економіко-правових досліджень

імені В. К. Мамутова Начіональної академіӥ наук Украйни

\section{ОСОБЛИВОСТІ ПРАВОВОГО РЕГУЛЮВАННЯ СОЦІАЛЬНО ВІДПОВІДАЛЬНИХ ПУБЛІЧНИХ ЗАКУПІВЕЛЬ ДЛЯ ПРОСУВАННЯ ПОВАГИ ТА ЗАХИСТУ ПРАВ ЛЮДИНИ У СФЕРІ БІЗНЕСУ}

\footnotetext{
Стаття присвячена питанням реалізаиії иілей із просування поваги та захисту прав людини у публічних закупівлях, які часто у науковій літературі розглядають як «горизонтальні» иілі, що $\epsilon$ додатковими до функиіональної мети закупівель. У роботі досліджується досвід ЄC, де, відповідно до Директив у сфері закупівель 2014 р., створено більш сприятливі умови країнам-иленам ЄС для стратегічного використання публічних закупівель, у межах яких можуть бути вирішенні питання, наприклад, прачевлаштування осіб, які тривалий час є безробітними. При ивому окрема увага приділяється обмежувальному підходу у правовому регулюванні реалізації «горизонтальних» иілей з просування поваги та захисту прав людини у публічних закупівлях, що полягає в обов'язковому забезпеченні пов'язаності таких вимог з предметом закупівлі, що значно обмежує можливості застосування загальних вимог до учасників, зокрема реалізації політики корпоративної сочіальної відповідальності. Доводиться, що не всі вимоги із просування поваги та захисту прав людини є додатковими до функціональної мети закупівель. Зокрема, вимоги із забезпечення відповідності законодавству у сфері охорони прав людини, як внутрішні вимоги до закупівельного процесу, спрямовані на дотримання конкурениії і створення рівних умов для участі у закупівлі, а також передбачають закріплення негативного зобов'язання у вигляді утримання від вчинення певних дій $і$ не тягнуть додаткових зобов'язань як таких. Посилення таких вимог спрямоване саме на забезпечення рівних умов, шоб суб'єкти господарювання змагалися за критеріями якості та іншими перевагами товарів. У иьому контексті наголошується на важливій ролі вимог із просування поваги та захисту прав людини у ланщюгах поставок, особливо в умовах лібералізації міжнародної торгівлі. Акиентується увага на доиільності забезпечення дотримання мінімальних вимог, передбачених відповідними Конвенціями Міжнародної організачії праиі, саме у ланиюгу поставок, коли договір про закупівлю виконується за кордоном.
}

Ключові слова: публічні закупівлі, соціально відповідальні публічні закупівлі, права людини, трудові права, Угода про асоціацію з СС, Угода СОТ про державні закупівлі, «горизонтальні» цілі, чесна конкуренція, соціальний демпінг.

Постановка проблеми. Правове регулювання відносин у сфері публічних закупівель спрямоване на забезпечення досягнення найкращого результату (ефективності використання державних коштів), в основі якого традиційно знаходились закупівлі товарів, робіт та послуг найвищої якості за найменшу ціну. Однак все частіше до публічних закупівель інтегруються аспекти, які, на перший погляд, не $є$ притаманним закупівельному процесу, серед яких містяться вимоги щодо просування поваги та захисту прав людини у сфері бізнесу. Наприклад, у Великобританії діє Акт про сучасне рабство [1]. Вчинення учасником правопорушень, визначених у даному Акті, становить обов’язкову підставу для відмови в участі у процедурі закупівлі [2]. y Південно-Африканській Республіці публічні закупівлі активно використовуються для вирішення проблем дискримінації як наслідків режиму апартеїду [3]. 3 цією метою у Законі про розширення економічних можливостей для корінного африканського населення передбачено заохочення та необхідність преференційних публічних закупівель. У США на федеральному рівні активно проводиться політика 3 підтримки малого бізнесу під час здійснення публічних закупівель, зокрема суб'єктів господарювання, які належать жінкам та ветеранамінвалідам збройних сил США [3]. Директива Європейського Союзу (далі - СС) 2014/24/ СC про публічні закупівлі містить положення про резервацію права брати участь 
у процедурах публічних закупівель для спеціальних суб'єктів господарювання, які наймають людей з обмеженими можливостями, та суб'єктів господарювання, головною метою яких є соціальна і професійна інтеграція інвалідів та малозабезпечених осіб, або вони можуть забезпечувати виконання договорів про закупівлю у контексті захищених програм зайнятості за умови, що принаймні 30 \% працівників цих суб'єктів господарювання або програм становлять люди з обмеженими можливостями або працівники $з$ малозабезпечених верств населення [6]. Для системи публічних закупівель України такий підхід не $є$ новим. Наприклад, п. 6 Положення про закупівлі товарів, робіт і послу за державні кошти, затвердженого Постановою Кабінету Міністрів України № 921 від 17.10.2008 р. (втратила чинність), було передбачено надання переваги тендерній пропозиції, поданій підприємствами громадських організацій інвалідів, де кількість інвалідів становила не менше 50 \% середньооблікової чисельності штатних працівників облікового складу за рік, шляхом застосування преференційної поправки. Водночас у контексті адаптації вітчизняного законодавства до вимог СС та участі України в Угоді Світової організації торгівлі (далі СОТ) про державні закупівлі вимоги щодо просування поваги та захисту прав людини набувають нового значення, а саме як: засіб державного регулювання для реалізації національних цілей за відповідними напрямами державної політики; засіб захисту ринків публічних закупівель від недобросовісної конкуренції, так званого соціального демпінгу, але у деяких випадках - і як засібу для протекціонізму. Крім того, у межах виконання зобов'язань відповідно до Угоди про асоціацію з СС в Україні було прийнято нову редакцію ЗУ «Про публічні закупівлі», яка значним чином може вплинути на більш стратегічне використання закупівель, у тому числі для просування поваги та захисту прав людини у сфері бізнесу.

Аналіз останніх досліджень і публікацій. У зарубіжній науковій літературі питанням просування поваги та захисту прав людини у публічних закупівлях присвячено значну кількість наукових праць [6, с. 69-79; 7, с. 41-71; 8, с. 257-267; 9]. Однак в Україні дане питання залишається малодослідженим, що можна пояснити домінуючим наразі так званим економічним підходом до публічних закупівель [10], коли держава має діяти на шталт приватного покупця, утримуючись від реалізації додаткових цілей держаної політики, і коли в основу найкращого результату покладено критерій найнижчої ціни.
Мета статті полягає у дослідженні та встановленні взаємозв'язку публічних закупівель і прав людини. 3 цією метою буде проведено аналіз зарубіжної практики, насамперед СС. Дане дослідження не має на меті виявлення та вирішення проблем сумісності таких соціальних вимог 3 міжнародними угодами та зобов'язаннями у сфері публічних закупівель, які спрямовані на лібералізацію ринків закупівель, а має більш обмежену мету, зокрема, надати огляд практик захисту та просування поваги до прав людини у публічних закупівлях і сучасних тенденцій у правовому регулюванні.

Виклад основного матеріалу. Роль публічних закупівель як драйверу для просування поваги та захисту прав людини та сталого споживання визначена у 12-ій Цілі сталого розвитку (Забезпечення переходу до ращіональних моделей споживання $і$ виробниuтва), одним із завдань якої виступає сприяння забезпеченню сталої практики публічних закупівель відповідно до національних стратегій і пріоритетів. Це передбачає можливості для держав не тільки закуповувати найдешевші товари, роботи та послуги, але й надавати перевагу тендерним пропозиціям учасників, які відповідають трьом стовпам сталого розвитку: екологічному, економічному та соціальному. Наприклад, замовник може віддати перевагу учаснику, який має ефективну систему боротьби з примусовою працею або торгівлею людьми, що відповідає також і завданню 8.7. Цілі 8 (Вжити термінових та ефективних заходів для того, шоб викорінити примусову пращю, покінчити із сучасним рабством і торгівлею людьми та забезпечити заборону й ліквідачію найгіриих форм дитячої прачі, включаючи вербу вання та використання дітей-солдатів, а до 2025 р. покінчити з дитячою пращею у всіх ï формах). Донедавна сталі публічні закупівлі переважно концентрувались на питаннях захисту навколишнього середовища за допомогою «зелених» публічних закупівель. Однак нині відбувається процес досягнення рівнозначності трьох стовпів сталого розвитку на всіх етапах закупівельного процесу, де соціальний елемент відображає також просування та захист прав людини [9, с. 26].

Міжнародна організація зі стандартизації розробила керівництво щодо запровадження сталих закупівель ISO 20400. У даному документі сталі закупівлі визначаються як закупівлі необхідних товарів, робіт і послуг таким чином, щоб це давало користь не лише організації, яка закуповує, але і суспільству в цілому, при цьому мінімізуючи вплив на 
навколишнє середовище. Це досягається шляхом забезпечення гідних умов праці осіб, які працюють у постачальника; закупівлею «сталих» товарів, у випадках, де це можливо, і вирішенням соціально-економічних питань, таких як бідність і нерівність. Одним із принципів сталих закупівель визначено повагу до прав людини та етичну поведінку [11, с. 2].

Типовий закон Комісії Організації Об'єднаних націй з права міжнародної торгівлі (ЮНСІТРАЛ) щодо закупівель товарів (робіт) та послуг 2011 р., зокрема Керівництво з його прийняття [12], на відміну від попереднього закону 1994 р., розглядає поняття «сталих» публічних закупівель. При цьому права людини, дитяча праця, примусова праця чітко визначені як фактори соціального складника сталих публічних закупівель [12, с. 5].

Взаємозв'язок між публічними закупівлями та правами людини посилюється завдяки чіткому посиланню на публічні закупівлі у Керівних принципах ООН у сфері бізнесу та прав людини, згідно з якими держави мають заохочувати дотримання прав людини підприємствами, з якими вони здійснюють комерційні операції [13].

Директиви СС у сфері закупівель прямо не згадують права людини, посилаючись лише на поняття «соціальні питання або аспекти», визначення яких також не надається. Втім, у публікації Європейської комісії щодо соціально відповідальних публічних закупівель [14] захист та просування поваги до прав людини розглядаються як приклад соціальних питань, що можуть бути вирішені у публічних закупівлях. Крім того, до таких соціальних аспектів закупівель віднесено також і гідні умови праці, соціальну інклюзію, трудові та соціальні права, а також етичні аспекти торгівлі. У новій редакції ЗУ «Про публічні закупівлі» від 19.04.2020р. серед критеріїв оцінки пропозиції з'являеться нове поняття «заходи соціального захисту», що можна пов'язати з правами людини у публічних закупівлях. Крім того, серед критеріїв оцінки визначено і підготовку управлінських, наукових і виробничих кадрів, що можна пов'язати з правами на працю.

Важливо встановити взаємозв'язок між публічними закупівлями і правами людини. Як правило, просування та захист прав людини у публічних закупівлях розглядають як «горизонтальну» ціль [7; 15], тобто додаткову до основної функціональної цілі закупівлі, яка полягає у придбанні товарів, робіт та послуг, необхідних безпосередньо для виконання замовником своїх функцій. У Директивах СС у сфері публічних закупівель 2014 р. простежується значне посилення у напрямі більш стратегічного використання публічних закупівель, що дозволяє замовникам інтегрувати соціальні та «зелені» критерії до різних етапів закупівельного процесу і досягати своїх внутрішніх цілей за різними напрямами політики. Дані Директиви значною мірою враховують практику Суду СС щодо можливостей реалізації «горизонтальних» цілей у закупівлях, наприклад боротьби 3 безробіттям [16].

Нині відповідно до Директиви 2014/24/ ЄC замовник має право встановлювати вимоги до процесів виробництва товарів, робіт і послуг, які планується придбати. Відповідно до п. 99 Преамбули Директиви 2014/24/СС заходи, спрямовані на захист здоров'я працівників, залучених до процесів виробництва предмета закупівлі, сприяння соціальній інтеграції представників вразливих груп населення серед осіб, які мають виконувати договір про закупівлю, або спеціальне навчання навичкам, які необхідні для реалізації договору, можуть виступати критеріями оцінки тендерних пропозицій або умовами виконання договору про закупівлю. Так, замовник може прийняти рішення укласти договір про закупівлю із суб'єктом господарювання, який планує найняти найбільшу серед інших учасників кількість людей, які є тривалий час безробітними, 3 метою виробництва предмета закупівлі. Він також може враховувати конкретні умови праці для відповідних працівників. Однак важливо вказати, що такі вимоги можуть стосуватись лише тих працівників, які будуть безпосередньо брати участь у процесах виробництва, постачання та надання товарів, робіт та послуг, що виступають предметом договору про закупівлю [17]. Враховуючи основну мету правового регулювання відносин у сфері публічних закупівель в межах ЄC, а саме забезпечення функціонування внутрішнього ринку, складником якого виступає взаємне відкриття ринків публічних закупівель країн-членів ЄС, підхід до реалізації «горизонтальних» цілей, у тому числі просування поваги до прав людини, $€$ обмежувальним з метою недопущення дискримінації між учасниками. Це забезпечується шляхом встановлення правила щодо пов'язаності вимог з предметом закупівлі на всіх етапах закупівельного процесу. Тобто замовники можуть брати до уваги лише ті соціальні питання, які стосуються товарів, робіт та послуг, що виступають предметом договору про закупівлю, і не можуть застосовувати загальні вимоги безвідносно таких товарів, робіт і послуг, зокрема і вимоги щодо запровадження учасником закупівлі політики корпоративної соціальної відповідаль- 
ності, про що зазначено у п. 97 Преамбули Директиви 2014/24/СС про публічні закупівлі і що деякі автори вважають проблемним питанням, враховуючи політику СС у даній сфері [18]. Така вимога була запроваджена у рішеннях Суду $\mathrm{CC}$, який дозволив реалізацію «горизонтальних» цілей за відповідними напрямами державної політики лише відповідно до принципів недискримінації, прозорості та пропорційності, які лежать в основі ідеології функціонування внутрішнього ринку СС [19]. У контексті захисту прав людини у ланцюгах поставок деякі автори зазначають, що таке обмеження є проблематичним, оскільки виробництво товарів відбувається часто на великих підприємствах, що виконують роботу для багатьох брендів. Досить проблематично забезпечити, щоб умови, які висуваються до працівників, стосувались тільки тих, хто безпосередньо залучені до виробництва предмета договору про закупівлю [7, с. 62].

У межах виконання зобов'язань відповідно до Угоди про асоціацію з СС процеси інтеграції вимог щодо просування та захисту прав людини не оминули й Україну. Редакція ЗУ «Про публічні закупівлі» від 19.04.2020 p. передбачає нову підставу, на основі якої змовник приймає рішення про відмову учаснику в участі у процедурі закупівлі та відхиляє тендерну пропозицію, - притягнення згідно із законом службової (посадової) особи учасника процедури закупівлі, яку уповноважено представляти його інтереси під час проведення процедури закупівлі, фізичної особи, яка є учасником, до відповідальності за вчинення правопорушення, пов'язаного з використанням дитячої прачі чи будь-якими формами торгівлі людьми. Така підстава є новою і для ЄС, адже була запроваджена Директивами СС у 2014 р. і має чіткий зв'язок із соціально-відповідальними публічними закупівлями [20, с. 297]. Взагалі, запровадження у новій редакції ЗУ «Про публічні закупівлі» положень, що стосуються соціально відповідальних закупівель, врівноважує три стовпи, які лежать в основі сталого розвитку. Адже до цього публічні закупівлі в Україні розглядалися крізь призму лише захисту навколишнього середовища та економічного зростання.

Втім, виникає питання: просування поваги прав людини, враховуючи взагалі обов'язок держави захищати права людини, чи завжди становить саме додаткову «горизонтальну» ціль до функціональної мети публічних закупівель? Відповідь полягає у тому, що нині захист та просування прав людини набуває характеру невід'ємного складника чесної конкуренції у закупівлях, особливо у ланцюгах поставок, коли йдеться про міжнародні ринки публічних закупівель.

Просування та захист прав людини у публічних закупівлях не виступають додатковою «горизонтальною» ціллю, якщо такі вимоги пов'язані із забезпеченням відповідності законодавству у сфері охорони прав людини, адже вони здебільшого спрямовані на забезпечення рівних умов для участі у закупівлях і вже стають внутрішніми по відношенню до закупівельного процесу. Вони, як правило, передбачають закріплення негативного зобов'язання у вигляді утримання від вчинення певних дій і не тягнуть додаткових зобов'язань як таких. Особливо яскраво це проявляється у положеннях щодо аномально низької тендерної пропозиції. Так, відповідно до ст. 69 Директиви 2014/24/СС про публічні закупівлі замовники можуть вимагати від суб'єктів господарювання пояснення ціни або витрат, запропонованих у конкурсній пропозиції, якщо вони здаються надмірно низькими по відношенню до робіт, матеріалів або послуг. Замовник зобов'язаний відхилити пропозицію, якщо виявиться, що ціна є низькою внаслідок недотримання учасником відповідних зобов'язань у сфері охорони навколишнього середовища, соціального захисту та трудових прав згідно із законодавством ЄС, національним законодавством, колективними договорами та положеннями міжнародних документів, визначених у відповідному Додатку до Директиви, наприклад Конвенції Міжнародної організації праці (далі - МОП) про примусову чи обов'язкову працю № 29 , Конвенції МОП про мінімальний вік для прийому на роботу № 138; Конвенції МОП про заборону та негайні заходи щодо ліквідації найгірших форм дитячої праці № 182.

Нова редакція ЗУ «Про публічні закупівлі» від 19.04.2020р. також запровадила механізм визначення аномально низької ціни тендерної пропозиції, що є новим поняттям для законодавства України про публічні закупівлі. Аномально низька ціни тендерної пропозиції визначається як ціна найбільш економічно вигідної пропозиції за результатами аукціону, яка є меншою на 40 або більше відсотків від середньоарифметичного значення ціни тендерних пропозицій інших учасників на початковому етапі аукціону, та/або є меншою на 30 або більше відсотків від наступної ціни тендерної пропозиції за результатами проведеного електронного аукціону. Учасник з такою аномально низькою ціною повинен надати обгрунтування щодо цін або вартості відповідних товарів, робіт чи послуг пропозиції. Таке обгрунтування може містити інформацію про досягнення економії 
завдяки застосованому технологічному процесу виробництва товарів, порядку надання послуг чи технології будівництва; сприятливі умови, за яких учасник може поставити товари, надати послуги чи виконати роботи, зокрема спеціальну цінову пропозицію (знижку) учасника; отримання учасником державної допомоги згідно із законодавством. При цьому ЗУ «Про публічні закупівлі» не вирішує питання щодо досягнення аномально низької ціни тендерної пропозиції внаслідок недотримання вимог законодавства у сфері соціального захисту та трудових прав, що потребує внесення відповідних змін. Адже держава, яка експортує, може отримати нечесну перевагу, наприклад, застосовуючи тяжкі умови праці. Чесні учасники втрачають інтерес та мотивацію брати участь у таких закупівлях. Тобто підстава для відхилення аномально низької ціни тендерної пропозиції внаслідок недотримання учасником відповідних зобов'язань у сфері соціального захисту та трудових прав є важливим складником добросовісної конкуренції. У СС прямо зазначається, що ці нові положення спрямовані на боротьбу саме із соціальним демпінгом [17].

Важливо наголосити на роз'ясненні Європейської комісії 2019 р. щодо участі постачальників та товарів із третіх країн на ринку публічних закупівель ЄС, згідно 3 яким стратегічні закупівлі не лише забезпечують більш відповідальне та стратегічне використання державних коштів, підтримку інвестицій, але і допомагають встановити рівні та чесні умови, забезпечуючи те, що всі учасники мають слідувати однаковим стандартам, незалежно від їх походження [21]. Це може виступати додатковим підтвердженням того, що такі внутрішні вимоги € невід'ємним складником конкуренції у публічних закупівлях.

У цьому аспекті важливу роль відіграє дотримання прав людини саме у ланцюгах поставок. Відповідно до даних МОП, у 2016 р. 24,9 млн людей були жертвами примусової праці. 3 них 16 млн експлуатувались у приватному секторі економіки. Незаконні прибутки, отримані внаслідок використання такої праці, становлять 150 млрд. дол. США на рік, більша частина яких припадає на ланцюг поставок [22]. Даній проблемі нині приділяється значна увага [23, с. 351-366; 24], особливо у контексті розвитку міжнародної торгівлі і систематичного розширення членства Угоди СОТ про державні закупівлі, учасницею якої Україна виступає з травня 2016 р.

у ЄC 3 прийняттям Директив у сфері закупівель 2014 р. було зроблено декілька важливих кроків та підготовлено основу для подальшого вирішення проблем дотримання мінімальних вимог у сфері охорони навколишнього середовища, соціального захисту та трудових прав у ланцюгах поставок. Так, у Директиві 2014/24/ЄС у п. 105 Преамбули чітко зазначено важливість дотримання субпідрядниками відповідних вимог у сфері охорони навколишнього середовища, соціального захисту та трудових прав, визначених національним законодавством, нормативно-правовими актами СС, колективними угодами, міжнародними документами, наведеними у додатку до Директиви, зокрема Конвенціями МОП. Тобто замовники мають забезпечити відповідність вимогам, якіє є чинними у місці, де виконуються роботи або надаються послуги. Будь-якому учаснику, який не виконує відповідні зобов’язання, має бути відмовлено в участі у закупівлі.

Визначений у Директиві 2014/24/СС перелік Конвенцій МОП може сприяти дотриманню мінімальних вимог у сфері прав людини саме у міжнародних ланцюгах поставок - це: 1) Конвенція про примусову чи обов’язкову працю № 29; 2) Конвенція про свободу асоціації та захист права на організацію №87; 3) Конвенція про застосування принципів права на організацію і на ведення колективних переговорів № 98; 4) Конвенція про рівне винагородження чоловіків і жінок за працю рівної цінності № 100; 5) Конвенція про скасування примусової праці № 105; 6) Конвенція про дискримінацію в галузі праці та занять № 111; 7) Конвенція про мінімальний вік для прийому на роботу № 138; 8) Конвенція про заборону та негайні заходи щодо ліквідації найгірших форм дитячої праці № 182. При цьому деякі автори зазначають, що цей перелік Конвенцій охоплює лише окремі права людини і залишає поза увагою ті права, які мають вагоме значення саме у ланцюгах поставок [7, с. 63]. Втім, країни-члени $\mathrm{CC}$ активно запроваджують вимоги щодо дотримання відповідних Конвенцій МОП у публічних закупівлях. Наприклад, у Законі про публічні закупівлі Королівства Швеція передбачено, що замовник має право вимагати від субпідрядника, який залучений до виконання робіт та надання послуг відповідно до договору про закупівлю, дотримуватись мінімальних соціальних стандартів: «У разі необхідності, якщо договір про закупівлю виконується за умов, коли право Швеції не застосовується, замовник може встановлювати вимоги, щоб учасник виконував договір відповідно до основних конвенцій Міжнародної організації праці» [25]. На важливості дотримання відповідних мінімальних вимог у сфері прав людини відповідно до Конвенцій МОП, 
якщо договір про закупівлю виконується за кордоном, наголошує і законодавство Швейцарської конфедерації [26, с. 73-78; 27].

Досить жорстких правил щодо дотримання та просування прав людини у публічних закупівлях дотримується Королівство Данія [28, с. 333-345], у тому числі у ланцюгах поставок. Враховуючи право замовника, передбачене ст. 70 Директиви 2014/24/€С, щодо застосування спеціальних умов договору про закупівлю, до яких можуть належати соціальні аспекти та питання щодо працевлаштування, значна кількість замовників передбачають цілі розділи у договорах, присвячених сталим закупівлям, у яких істотна частина відведена положенням щодо захисту та просуванню прав людини. Переважно такі положення грунтуються на Десяти Принципах Глобального Договору ООН [29], Керівних принципах $\mathrm{OOH}$ у сфері бізнесу і прав людини та Конвенціях МОП. Як приклад таких розділів у договорах наводяться такі вимоги: 1) права людини (учасник зобов'язується під час виконання договору поважати права людини згідно з принципами 1 та 2 Глобального договору ООН та положеннями Конвенцій МОП № 100 щодо рівного винагородження праці чоловіків і жінок та Конвенції № 111 про дискримінацію в галузі праці); 2) трудові права, включаючи вимоги щодо мінімальної заробітної плати (учасник зобов'язується поважати основні трудові права працівника, щоб товари та їх частини вироблялись у безпечних умовах, у тому числі відповідно до положень Конвенції МОП № 155 «Про безпеку й гігієну праці та виробниче середовище») [28, с. 337]. При цьому зазначається, що на практиці часто виникають проблемні питання, пов'язанні iз забезпеченням виконання таких вимог та встановленням відповідальності за їх порушення, враховуючи, що, наприклад, Глобальний договір ООН є за своєю природою добровільним механізмом, що використовує досить загальні положення. Крім того, як вже було зазначено вище, зобов'язання щодо пов'язаності вимог з предметом закупівлі обмежують право замовників враховувати наявність або відсутність в учасника загальної політики корпоративної соціальної відповідальності.

У ЗУ «Про публічні закупівлі» стосовно субпідрядників у закупівлях встановлена лише вимога щодо зазначення учасником у тендерній пропозиції інформації (повне найменування та місцезнаходження) щодо кожного суб'єкта господарювання, якого учасник планує залучати до виконання робіт чи послуг як субпідрядника/співвиконавця в обсязі не менше 20 \% від вартості договору про закупівлю. Однак ЗУ «Про публічні» закупівлі не вирішує питання щодо дотримання мінімальних вимог у сфері захисту прав людини як складника чесної конкуренції у ланцюгу поставок, що потребуе вирішення, особливо в умовах лібералізації ринку публічних закупівель відповідно до Угоди про асоціацію з СС та Угоди СОТ про державні закупівлі.

\section{Висновки.}

Доведено посилення тенденцій широкої інтеграції додаткових вимог з просування поваги та захисту прав людини у законодавство і практику здійснення публічних закупівель як у зарубіжних країнах, так і в Україні.

Аргументовано, що вимоги із захисту та просування поваги до прав людини виступають не лише додатковими, порівняно з функціональною метою закупівель, цілями, але у деяких випадках і невід'ємним внутрішнім складником публічних закупівель. Активна інтеграція таких вимог зумовлена:

1) новою ідеологією життя на основі принципів сталого розвитку, адже публічні закупівлі є невід'ємним складником досягнення відповідних Цілей сталого розвитку. У даному випадку закупівлі сприяють досягненню внутрішніх стратегічних цілей за різними напрямами політики ЄС. Незважаючи на відповідні обмеження Директив ЄC у сфері закупівель щодо реалізації соціальних вимог у закупівлях, враховуючи їхню обов'язкову пов'язаність $з$ предметом закупівлі, слід констатувати значний прогрес у забезпеченні можливостей для захисту та просування прав людини у публічних закупівлях;

2) необхідністю забезпечення добросовісної конкуренції, особливо у контексті лібералізації ринків публічних закупівель для міжнародної торгівлі, та боротьби з соціальним демпінгом. Посилення захисту прав людини у публічних закупівлях зумовлено також розширенням членства в Угоді СОТ про державні закупівлі, зокрема потенційним приєднанням до Угоди країн, що розвиваються, в яких часто фіксуються порушення прав людини під час процесів виробництва, учасники яких залучені як субпідрядники. У даному випадку вимоги щодо захисту прав людини вже можуть охоплювати не лише внутрішній, національний, але і міжтериторіальний аспект, особливо коли йдеться про ланцюги поставок.

Доведено, що важливим аспектом забезпечення добросовісної конкуренції, особливо у контексті інтеграційних процесів, які мають в основі мету лібералізації ринків публічних закупівель для міжнародної тор- 
гівлі, є дотримання прав людини у ланцюгах поставок. 3 цією метою пропонується передбачити встановлення вимоги до виконання договору про закупівлю, згідно з якою як учасник, так і субпідрядники, яких він залучає до виконання договору на території України, мають дотримуватись вимог щодо охорони та безпечних умов праці, а у разі виконання договору про закупівлю за кордоном - стандартів, які закріплені у Конвенціях Міжнародної організації праці (МОП).

\section{Список використаних джерел:}

1. Modern Slavery Act 2015. URL: https://www.legislation.gov.uk/ukpga/2015/30/ contents/enacted (last accessed: 01.10.2020).

2. The Public Contracts Regulations 2015. URL: https://www.legislation.gov.uk/uksi/2015/102 (last accessed: 29.09.2020).

3. Broad-based Economic Empowerment Act 53. 2003. URL: https://www.gov.za/documents/ broad-based-black-economic-empowerment-act (last accessed: 29.09.2020).

4. Set-asides for government contracting programs. U.S. Small Business Administration. URL: https://www.sba.gov/federal-contracting/ contracting-guide/types-contracts\#sectionheader-0 (last accessed: 29.09.2020).

5. On public procurement and repealing Directive 2004/18/EC: Directive 2014/24/EU of the European Parliament and of the Council of 26 February 2014. OJ. 2014. L 94. P. 65-242.

6. Martin-Ortega O., O'Brien C.M. Advancing Respect for Labour Rights Globally through Public Procurement. Politics and Governance. 2017. Vol. 5. Issue 4. P. 69-79.

7. Outhwaite O., Martin-Ortega O. Human Rights in Global Supply Chains. Corporate Social Responsibility and Public Procurement in the European Union. Human Rights \& International Legal Discourse (HR E $\mathcal{F}$ ILD). 2016. № 1. P. 41-71.

8. McCrudden C. Using public procurement to achieve social outcomes. Natural Resources Forum. 2004. № 28. P. 257-267.

9. Driving Change Through Public Procurement: A Toolkit on Human Rights for Procurement Policy Makers and Practitioners. The Danish Institute for Human Rights. 2020. URL: https://www.humanrights.dk/sites/ humanrights.dk/files/media/dokumenter/ udgivelser/hrb_2020/dihr_toolkit_public procurement_2020 $72 \mathrm{dpi} . p \mathrm{df}$ - (last accessed: 30.09.2020).

10.Trepte P. Regulating Procurement. Understanding the Ends and Means of Public Procurement Regulation. USA : Oxford University Press, 2004. 411 p.

11. Sustainable procurement. An overview of the standard and how it can benefit your organization. ISO. URL: https://www.iso.org/files/live/sites/ isoorg/files/store/en/ISO\%2020400_Sustainable_ procur.pdf (last accessed: 29.09.2020).
12. Guide to Enactment of the UNCITRAL Model Law on Public Procurement. Unites Nations Commission on International Trade Law. URL: https://www.uncitral.org/pdf/english/texts/ procurem/ml-procurement-2011/GuideEnactment-Model-Law-Public-Procurement-e.pdf (last accessed: 29.09.2020).

13. Керівні принципи ООН з питань бізнесу та прав людини: Реалізація Рамкової програми ООН «Захист, повага і засоби захисту». URL: https://legalforum.nlu.edu.ua/wp-content/ uploads/2018/11/UNGP-Ukrainian.pdf (дата звернення: 12.05.2020)

14. Buying social. A Guide to Taking Account of Social Considerations in Public Procurement. European Commission. URL: https://op.europa.eu/ en/publication-detail/-/publication/cb70c4810e29-4040-9be2-c408cddf081f (last accessed: 30.09.2020).

15. Arrowsmith S. Horizontal policies in public procurement: a taxonomy. Journal of public procurement. 2010. Vol. 10. Issue 2. P. 149-186.

16. Case 31/87, Gebroeders Beentjes BV v State of the Netherlands. ECR 1988-04635. 1988. Para. 20. URL: http://curia.europa.eu/juris/showPdf.jsf?text $=\&$ docid $=95121 \&$ pageInde $x=0 \&$ doclang $=$ en $\&$ mode $=$ req \&dir $=\&$ occ $=$ first $\&$ part $=1 \&$ cid $=14635784$ (last accessed: 25.09.2020).

17. Public Procurement Reform. Fact Sheet № 8: Social Aspects of the New Rules. URL: https://ec.europa.eu/docsroom/documents/ 15526/attachments/1/translations/en/renditions/ native (last accessed: 30.09.2020).

18. Ankersmit L. The contribution of EU public procurement law to corporate social responsibility. European Law Journal. 2020. P. 1-18.

19. Concordia Bus Finland. E.C.R. I-07213. 2002. URL: http://curia.europa.eu/juris/liste. jsf?language $=$ en\&num $=\mathrm{C}-513 / 99$ (last accessed: 25.07.2020)

20. Semple A. Socially Responsible Public Procurement under EU Law and International Agreements: The GPA, CETA and the EU-Ukraine Deep and Comprehensive Free Trade Area. European Public Procurement and Public Private Partnership Lazo. 2017. Vol. 12. Issue 3. P. 293-309.

21. Guidance on the participation of third-country bidders and goods in the EU procurement market. Communication from the Commission. C (2019)5494 final. P.18. URL: https://ec.europa.eu/ transparency/regdoc/rep/3/2019/EN/C-20195494-F1-EN-MAIN-PART-1.PDF (last accessed: 20.07.2020)

22. Forced labour, modern slavery and human trafficking. International Labour Organization. URL: https://www.ilo.org/global/topics/ forced-labour/lang--en/index.htm (last accessed: 20.02.2020).

23. Amann M., Roehrich J.K., Essig M., Harland C. Driving sustainable supply chain management in the public sector: The importance of public procurement in the EU. Supply Chain Management: An International Journal. 2014. Vol. 19 No. 3. P. 351-366. 
24. Martin-Ortega O., Outhwaite O., Rook W. Promoting responsible electronics supply chains through public procurement. University of Greenwich. 2015. URL: https://www.hrprocurementlab. org/wp-content/uploads/2016/04/UoG-SRPPpolicy-paper-January-2015-ad.pdf (last accessed: 30.09.2020).

25. Swedish Public Procurement Act. URL: http://www.konkurrensverket.se/globalassets/ english/publications-and-decisions/swedish-public-procurement-act.pdf (last accessed: 15.09.2019).

26. Steiner M. Is There a Swiss Approach Towards Sustainable Public Procurement? Euro- pean Procurement \& $\mathcal{\sigma}$ Public Private Partnership Law Reviez. 2013. № 8. P. 73-78.

27. Sustainable Procurement. Recommendations for the federal procurement offices. Federal Department of Finance, Federal Office for Buildings and Logistics, Office of the Swiss Federal Procurement Conference. 2014. Switzerland. 26 p.

28. Andrecka M. Corporate Social Responsibility and Sustainability in Danish Public procurement. European Public Procurement \& Public Private Partnership. 2017. № 3. P. 333-345.

29. United Nations Global Compact. URL: https:// www.unglobalcompact.org (last accessed: 30.09.2020).

Vesta Malolitneva. Legal regulation of socially responsible public procurement for protecting against human rights abuse and encouraging respect for human rights in business

The present article is dedicated to the implementation of the goals on protection and encouraging respect for human rights in public procurement, which are often considered as "horizontal" aims in relation to the functional purpose of procurement. The paper examines the experience of the EU, the legal regulation of which is characterized by assisting the EU Member States in a more strategic use of public procurement, which may address issues such as an employment of long-term job-seekers. At the same time, special attention is paid to the restrictive approach in the legal regulation of "horizontal" goals implementation to promote respect and protection of human rights in public procurement, due to the condition of a link with the subject-matter of the contract, which significantly limits the application of general requirements to economic operators, in particular the implementation of corporate social responsibility policy. It turns out that not all requirements on promotion of respect and protection of human rights are additional to the functional purpose of procurement. In particular, the requirements on compliance with the provisions on protection of human rights, as internal requirements for the procurement process, aimed at maintaining competition and creating a level playing field for participation in procurement. These requirements provide for the consolidation of a negative obligation in the form of refraining from certain actions and do not entail additional obligations as such. Strengthening such requirements is aimed at ensuring a level playing field so that businesses could compete on the criteria of quality and other advantages of supplies. In this context, the important role of requirements for the promotion of respect and protection of human rights in the supply chain is emphasized, especially in the context of international trade liberalization. The author gives special consideration to the importance of ensuring compliance with the minimum requirements of the relevant ILO conventions in the supply chain when the contract is performed abroad.

Key words: public procurement, socially responsible public procurement, human rights, labor rights, EU-Ukraine Association Agreement, WTO Government Procurement Agreement, "horizontal" goals, fair competition, social dumping. 